\title{
Representation of Students' Politeness During Online Learning: A Case Study at IAIN Madura
}

\author{
Iswah Adriana $^{1 *}$, Agus Purnomo Ahmad Putikadyanto ${ }^{2}$, Agik Nur Efendi ${ }^{3}$ \\ ${ }^{123}$ Indonesian Language Education Study Program, Institute of Islamic Religion Madura \\ "Corresponding author. Email: iswahadriana@gmail.com
}

\begin{abstract}
The study of politeness is very important to do on student speech to their lecturers in online lectures during this pandemic. The student's utterances conveyed to their lecturers through the WhatsApp (WA) application sometimes ignore the politeness rule because it is done online. In this study, the researcher tried to analyze it using the theory of politeness which was proclaimed by Pranowo in pragmatics. The data in this study are in the form of speeches by IAIN Madura Indonesian Language Education Study Program students when communicating with their lecturers at WAG in online lectures. The data sources are some screenshots of speeches by IAIN Madura Indonesian Language Education Study Program students when communicating with their lecturers in WA in online lectures. The data collection technique in this study is the listening and speaking technique and the note-taking technique. The data were analyzed descriptively critically. From the results of the study, it was found: (1) The existence of speech forms that adhere to politeness which includes angon rasa, fighting, empan papan, humility, respect, tepa selira, and the use of the diction "sorry", "thank you", and greeting words.; (2) The existence of speech forms that violate politeness which includes the speaker expressing criticism directly and with harsh words, the speaker deliberately corners the speech partner in speaking and also the speaker's inaccurate and precise word selection.
\end{abstract}

Keywords: language politeness, students, online lectures.

\section{INTRODUCTION}

Every human being will not be separated from the activity called communication. With communication, humans are required to have good knowledge of the rules governing the use of language in communication [1]. Language is a reflection of the personality of the person who speaks it [2]. That is, through the use of language a person can know his personality. Good or bad someone will be seen through the language used and the behaviour shown. A person's personality will be difficult to measure if they do not express their thoughts or feelings through language acts, both verbal and nonverbal [3].

Language is not enough just to obey the rules, but also to apply politeness which is used to establish a relationship between the speaker and the addressee [4]; [5]. Being polite is one of the cultures in Indonesia that should be applied every time you communicate with other people. Speech is called polite if it does not sound pushy or arrogant, it gives a choice of action to the interlocutor, and the interlocutor becomes happy [6]. In other words, whether or not a person is polite can be measured through the verbal and nonverbal language used. By speaking politely, a person can maintain his dignity by respecting others. However, often this hope is still far away because the willingness to accept others as they are (empathy), sincerely appreciate the success of others, and have sympathy for the suffering of others is still very difficult to implement [3]. "Politeness of language" is reflected in the procedure for communicating through verbal signs. Chaer emphasized that politeness refers to elements of language, such as sentences, or expressions [6] .

As is known pragmatics is a branch of linguistics that studies the language used to communicate in certain situations [7]. Therefore, politeness becomes part of a pragmatic study, where the politeness indicator used relies on the politeness theory promoted by Pranowo. Politeness indicators are markers that can be used as a determinant of whether a person's use of Indonesian is polite or not. These markers can be in the form of linguistic elements or non-linguistic elements [3]. 
Although Pranowo's theory of politeness uses many Javanese terms such as angon rasa, adu rasa, empan Papan, and tepa selira, it does not mean that the theory can only be applied to Javanese speakers with Javanese culture. Pranowo's theory of politeness is very possible to be applied to Indonesian speakers with multicultural backgrounds, such as students and students of the Indonesian Language Education Study Program at IAIN Madura who are Madurese speakers.

During the COVID-19 pandemic, IAIN Madura students conducted online lectures using several applications. In addition to using e-learning applications that have been set by the campus, students also communicate with their lecturers using WAG in each of their courses. From here, sometimes some of them ignore a communication, which must still heed politeness because they use written language. Although our communication uses written language, basically we still communicate verbally. As is known, the determinants of politeness in addition to the linguistic aspect must also pay attention to non-linguistic aspects as well. In the linguistic aspect, it includes spoken verbal language which must pay attention to matters relating to intonation, tone, choice of words and sentence structure. While in written verbal language, you still have to pay attention to word choice and sentence structure. Non-linguistic aspects which include socio-cultural institutions that apply in society, the topics discussed and the context around communication events are also very important to be considered by every speaker in the communication process [3].

Based on the above phenomenon, the researcher is interested in photographing the politeness utterances of Indonesian Language Education Study Program students at IAIN Madura when communicating with their lecturers at WAG in online lectures. As Madurese speakers, they will not be separated from the Madurese culture which is their identity. That's why the researcher chose to use Pranowo's politeness theory as the basis for his analysis.

\section{METHODOLOGY}

This research is included in the type of qualitative descriptive research. Research by collecting descriptive data is research that is carried out solely based on facts and phenomena that are empirically alive in the speakers so that what is produced or recorded is in the form of language descriptions that can be said to be like representations [8]. Mahsun stated that qualitative analysis focuses on indicating the meaning, description, clarification, and placement of data in their respective contexts and often describes them in the form of words rather than numbers [9].

The data in this study are qualitative in the form of words, phrases, clauses, and sentences from the speech results of IAIN Madura Indonesian Language Education Study Program students when communicating with their lecturers in WA in online lectures. Education Study Program when communicating with lecturers in WA in online lectures.

The method used in this study is the free-toconversation listening method with advanced techniques of note-taking techniques. According to Sudaryanto, in this technique the researcher is not directly involved in the dialogue or conversation, the researcher only acts as an observer and listens to what the speaker is saying [8].

The steps in the data collection process. 1. Listening to the speech of IAIN Madura Indonesian Language Education Study Program students when communicating with their lecturers in WA in online lectures 2. Identifying speech containing politeness 3 . Storing data that has been identified as containing politeness by using screenshots 4 . Recording data that has been saved to the data transcript sheet.

The steps used in analyzing research data are as follows. 1. Collect data in the form of several screenshots of speeches by IAIN Madura students of TBIN study program when communicating with their lecturers in WA in online lectures containing politeness 2. Identifying data based on indicators and determinants of politeness according to Pranowo 4. Classifying data based on indicators and the determinants of politeness according to Pranowo 5. Analyzing data on the realization of politeness in the speech of IAIN Madura Indonesian Language Education Study Program students in the form of classified compliance or violations. Sixth, to conclude research data.

The data were analyzed descriptively critically. That is, the data is analyzed by describing the phenomenon of language as it is, but is criticized by using a politeness approach. Data analysis relies on the theory of politeness promoted by Pranowo [3]. Although Pranowo's theory of politeness uses many Javanese terms such as angon rasa, adu rasa, empan Papan, and tepa selira, it does not mean that the theory can only be applied to Javanese speakers with Javanese culture. Pranowo's theory of politeness is very possible to be applied to Indonesian speakers with multicultural backgrounds, as well as to Madurese culture.

\section{ANALYSIS}

\subsection{The form of speech by IAIN Madura students who adhere to politeness according to Pranowo}

In a study of politeness IAIN Madura students who comply with the indicators of politeness proposed by Pranowo are as follows:

a. Angon Rasa (Weighing Taste), namely communication carried out by speakers by keeping the feelings of the speech partners so that when they 
speak they can make the hearts of the speech partners happy. As the data in the following speech:

"Sorry ma'am at 8:15 it's already past ma'am.. maybe you mean 9:15

"Madam, I apologize for being absent at WAG because my E-learning keeps on connecting"

"Okay ma'am thank you, sorry ma'am, I didn't mean to double mom"

"Sorry for the negligence of group 4A and B ma'am"

b. Adu Rasa (empathy), meaning that the speaker brings his feelings together with the feelings of the speech partner so that the contents of the communication are equally desired because they are equally desired [3]. This can be seen in the following speech data:

"Ready ma'am we are waiting"

c. Empan Papan (According to the Situation), the speaker can maintain his speech so that when a subject needs to be conveyed, the situation and conditions must be taken into account [3]. The speech that shows the four boards is as follows:

"God willing, mother, in the future even more enthusiastic"

d. Humble, namely speech that shows the speaker's sense of incompetence in front of the speech partner. As in the following speech:

"Sorry if the answer is wrong because I'm only human"

"Sorry in advance if there is a mistake in asking"

"Sorry if there is an error in my question"

"I'm sorry if you from group 4A still have many shortcomings"

\subsection{The form of speech by IAIN Madura students that violates politeness according to Pranowo}

Pranowo [3] also revealed a theory about impolite communication indicators. Because communication that is not polite occurs frequently, although there are numerous methods to speak and communicate politely. The following [10]) are examples of warning signs:

a. The speaker expresses criticism directly and with harsh words. Indonesian culture, especially Madurese culture, always emphasizes uploading. So in speaking with other people must be explained first and then reveal the point. So that the speech partner can understand and not be offended by what is said. Especially if it contains criticism. This can be seen in the following student speech data:

"Come sit cross-legged with us, so you guys know the taste.." "too fast"

"Right now it's not the quota that I'm talking about, doesn't it have a sense of humanity"

b. The speaker deliberately corners the speech partner in speaking. This sometimes happens if someone wants to win his opinion and wants to be considered correct about his opinion, causing pressure and discomfort to his partner. As in the following student speech data:

"I'm sorry ma'am, because earlier in the group there were no rules for using ballpoints. Now is the month offasting, ma'am."

c. Diction accuracy, namely the accuracy of the use of words to express meaning and intent in a certain context so that it has a certain effect on the speech partner. The choice of words that are not careful and precise can reflect a sense of impoliteness, for example:

"if you can send the material here too ma'am"

"The majority can't log in, ma'am, it would be nice if the lectures could be focused on WAG Ma'am"

The utterance above seems less polite because it forces the interlocutor to do something, and also uses direct sentences to order the interlocutor who is older than the speaker.

"Alhamdulillah, you are healthy, ma'am.. If samean (you) are healthy yourself, ma'am.."

The use of the word you above is not polite if it is used to refer to the second adult.

\section{CONCLUSION}

The speech forms of IAIN Madura students who adhere to politeness according to Pranowo's politeness indicators include Angon Rasa (Weighing Taste), Adu Rasa (Empathy), Empan Papan (According to Situation), Humble, Respectful Attitude, Tepa Selira (Empathy), and also the accuracy of diction which includes the use of the phrase "thank you" as a tribute to the kindness of others, the word "sorry" for speech that is thought to offend others, and the word "sir/mom" to refer to the second adult.

The speech forms of IAIN Madura students who violate politeness according to Pranowo's politeness indicators include the speaker expressing criticism directly and with harsh words, the speaker deliberately corners the speech partner in speaking and also the choice of words that are not careful and precise by the speaker.

\section{REFERENCES}

[1] Mowlana, H. (2019). Human communication 
theory: a five-dimensional model. The Journal of International Communication , 25(1), 3-33.

[2] Lu, Y., \& Gnevsheva, K. (2021). Accentedness and personality evaluation of Asian and Caucasian second language speakers of English by Asian second language English listeners. Journal of Multilingual and Multicultural Development.

[3] Pranowo. (2009). Berbahasa Secara Santun. Yogyakarta: Pustaka Pelajar.

[4] Abudayeh, H., \& Dubbati, B. (2020). Politeness strategies in translating Donald Trump's offensive language into Arabic. Perspectives Studies in Translation Theory and Practice, 28(3), 424-439. https://doi.org/10.1080/0907676X.2019.1709514

[5] Jegarlooei, S. H. M., \& Allami, H. (2018). (Im)politeness strategies and use of discourse markers. Cogent Arts \& Humanities , 5(1).

[6] Chaer, A. (2010). Kesantunan berbahasa. Rineka Cipta.

[7] Nadar, F. X. (2009). Pragmatik dan Penelitian Pragmatik. Yogyakarta: Graha Ilmu.

[8] Sudaryanto. (1993). Metode dan aneka teknik analisis bahasa: Pengantar penelitian wahana kebudayaan secara linguistis. Duta Wacana University Press.

[9] Mahsun. (2005). Metode Penelitian Bahasa: Tahapan Strategi, Metode, dan Tekniknya. Jakarta: Rajawali Pers.

[10] Sukmawan, S. (2009). Simfoni Bahasa Indonesia. Malang: Universitas Brawijaya Press. 